This item was submitted to Loughborough's Research Repository by the author.

Items in Figshare are protected by copyright, with all rights reserved, unless otherwise indicated.

\title{
Contemporary Mappa Mundi: American exceptionalism in the world city
} network

PLEASE CITE THE PUBLISHED VERSION

http://dx.doi.org/10.1068/a4352

PUBLISHER

(C) Pion

VERSION

AM (Accepted Manuscript)

LICENCE

CC BY-NC-ND 4.0

REPOSITORY RECORD

Vinciguerra, Sandra, Peter J. Taylor, Michael Hoyler, and Kathryn Pain. 2019. "Contemporary Mappa Mundi: American Exceptionalism in the World City Network”. figshare. https://hdl.handle.net/2134/6522. 
This item was submitted to Loughborough's Institutional Repository (https://dspace.lboro.ac.uk/) by the author and is made available under the following Creative Commons Licence conditions.

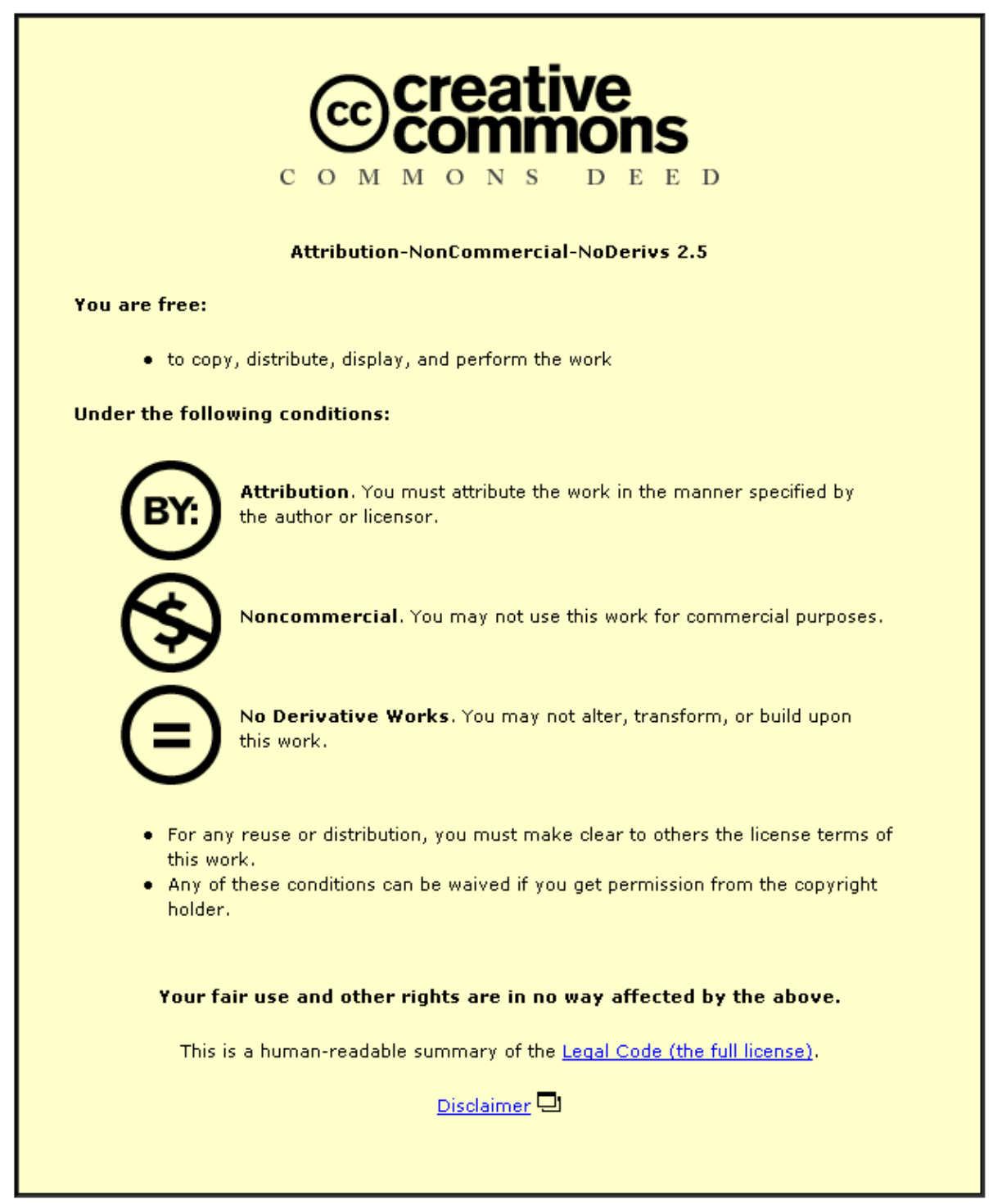

For the full text of this licence, please go to: http://creativecommons.org/licenses/by-nc-nd/2.5/ 


\section{Contemporary Mappa Mundi: American exceptionalism in the world}

city network

Sandra Vinciguerra*, Peter J Taylor*, Michael Hoyler* and Kathy Pain**

*Department of Geography, Loughborough University, UK

${ }^{* *}$ School of Real Estate \& Planning, University of Reading, UK

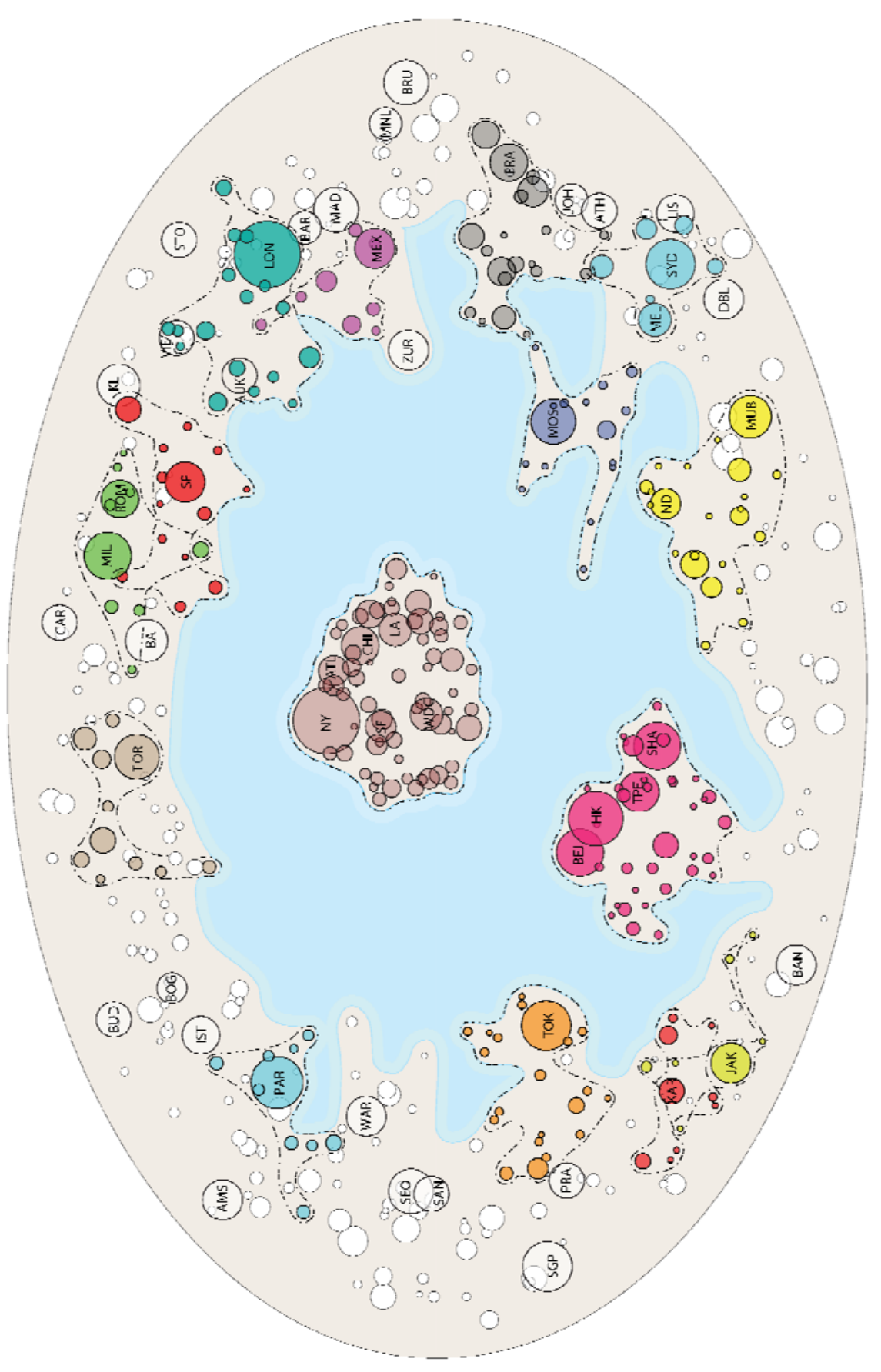


American exceptionalism has come in many forms, varying from its distinctive party politics and its unusual religiosity to its particular professional sports. This graph adds global urban geography to the list.

The graph derives from a visualization exercise to aid in presenting Globalization and World Cities (GaWC) world city network research. It has been created using the spring embedding algorithm on a $506 \times 506$ intercity matrix derived from the office networks of 175 advanced producer firms. The iterative process was constrained by country identification (details at http://www.lboro.ac.uk/gawc/rb/rb335.html).

On this graph the US cities could hardly be more exceptional. They cluster as an 'island' at the centre of the world with no other cities nearby. All the remaining cities form an outer ring away from the USA. Generally speaking, Asian cities are to be found in the 'southern' parts of the ring, and European cities share the 'northern' part of the ring with Latin American cities. The American island appears to be weighted towards the 'north', by the presence of Chicago, Atlanta, and, above all, New York. In the European cities in the 'north', none of the major nodes is as 'coastal' as New York. In fact, this region tends to be fairly transnational with overlapping state boundaries. In contrast, for the Asian cities in the 'south', such overlapping is much rarer, and more leading cities are 'coastal' (i.e. facing the centre). This is very much the case with China, as its four leading cities seem to be pulling the country into the centre of the graph. China appears to be drawing away from its rivals: it is cutting off a faltering Japan, faces a weak challenge from Russia, while India, especially Mumbai, has yet to begin its push. China's challenge to American centrality, and maybe its exceptionalism, could hardly be more clearly displayed.

In the medieval world, the famous Mappa Mundi had Jerusalem at its centre; this contemporary Mappa Mundi has the USA so positioned. But for how much longer?

\section{Acknowledgements}

ESRC (RES-000-22-3575), Professor Pengfei Ni (CASS) and Professors Ben Derudder and Frank Witlox (Ghent), and Mark Szegner (Loughborough). 